\title{
RANCANGAN APLIKASI PENJUALAN PADA TOKO BUKU SYAHPUTRA BERBASIS DESKTOP
}

\author{
Fadel Maulana Syahputra ${ }^{1}$, Za'imatun Niswati $^{2}$, Nunu Kustian ${ }^{3}$ \\ ${ }^{1,2,3}$ Teknik Informatika, Fakultas Teknik dan Ilmu Komputer,Universitas Indraprasta PGRI Jakarta \\ Jalan Raya Tengah No 80, Kelurahan Gedong, Pasar Rebo, Jakarta Timur \\ 1Fadelmaulana15@gmail.com, ${ }^{2}$ niswati.aziz@gmail.com, ${ }^{3}$ kustiannunu@gmail.com
}

\begin{abstract}
ABSTRAK
Toko Buku Syahputra merupakan toko yang menyediakan produk buku dan alat tulis sekolah. Namun terdapat kendala dalam pengumpulan data dari proses penjualan, dimana seluruh transaksi penjualan dilakukan secara manual dengan mencatat di dalam buku besar, sehingga proses pencatatan, pencarian data dan transaksi penjualan rawan terjadi kesalahan yang dapat menyebabkan kerugian, selain itu pembuatan laporan untuk pemilik toko memakan waktu yang cukup lama. Tujuan penelitian ini adalah merancang aplikasi penjualan pada toko buku Syahputra untuk memproses pengolahan data transaksi menggunakan Java NetBeans 8.0.2 Metode penelitian yang digunakan adalah SDLC (Software Development Life Cycle) yang meliputi analisa kebutuhan, desain, implementasi, pengujian dan evaluasi atau pemeliharaan. Hasil dari penelitian ini adalah aplikasi penjualan memudahkan dalam pengolahan data dimana pengolahan data secara komputerisasi mempermudah admin dalam pengolahan data transaksi penjualan, proses pembuatan laporan menjadi efisien dan efektif, informasi lebih cepat, tepat dan akurat serta data tersimpan dalam sebuah database dan meminimalisir kesalahan proses transaksi penjualan.
\end{abstract}

Kata Kunci: Aplikasi Penjualan, Toko Buku, Desktop, SDLC (Software Development Life Cycle)

\section{ABSTRACT}

Syahputra Bookstore is a store that provides books and school stationery products. However, there are obstacles in collecting data from the sales process, where all sales transactions are carried out manually by recording in the ledger, so that the recording process, data search and sales transactions are prone to errors that can cause losses, besides making reports for shop owners takes time. which is quite long. The purpose of this study is to design a sales application at Syahputra's bookstore to process transaction data processing using Java NetBeans 8.0.2 The research method used is SDLC (Software Development Life Cycle) which includes needs analysis, design, implementation, testing and evaluation or maintenance. The results of this study are sales applications facilitate data processing where computerized data processing makes it easier for admins to process sales transaction data, the report generation process becomes efficient and effective, information is faster, more precise and accurate and data is stored in a database and minimizes transaction processing errors sale.

Key Word: Sales Application, Bookstore, Desktop, SDLC (Software Development Life Cycle)

\section{PENDAHULUAN}

Perkembangan globalisasi yang diiringi oleh kemajuan teknologi informasi mengakibatkan arus informasi yang dulunya sulit diperoleh, kini dapat diperoleh dengan mudah pada saat dibutuhkan. Perkembangan teknologi yang semakin maju membutuhkan kinerja yang relatif cepat dan akurat dalam suatu instansi atau bisnis untuk menghasilkan informasi yang dibutuhkan. Salah satunya adalah penerapan teknologi komputer sebagai penunjang utama dalam persaingan usaha dan penunjang sumber daya manusia yang baik. Untuk dapat menciptakan dan mengatasi kondisi tersebut maka diperlukan suatu sistem informasi yang dapat melayani segala macam aspek informasi mengenai kapasitas, keterampilan, keahlian, pengalaman dan potensi pegawai secara cepat dan tepat yang kemudian dapat digunakan untuk menentukan kebijakan atau keputusan dan implementasinya. agar dalam pengolahan data penjualan pada Toko Buku Syahputra bisa berkembang (Ali, 2019).

Toko Buku Syahputra merupakan toko yang menyediakan produk buku dan alat tulis 
sekolah. Namun terdapat kendala dalam pengumpulan data dari proses penjualan karena dilakukan secara manual dengan mencatat semua transaksinya didalam buku besar (Sholikhah, Sairan, \& Syamsiah, 2017).

Permasalahan yang paling penting adalah proses pemasukan data, proses transaksi penjualan dan pelaporan ini selalu dilakukan secara konvensional yaitu dengan mencatat semua transaksinya didalam buku besar, sehingga data yang diperoleh seringkali bermasalah karena human error, misalnya pada saat administrasi membutuhkan informasi mengenai stok barang masuk dan keluar yang harus diperiksa. menyimpan dan mengontrol barang. Pelaporan data penjualan seringkali terlambat saat mengirimkan laporan bulanan kepada manajer toko (Sari, 2017).

Diharapkan dengan adanya suatu aplikasi penjualan dapat menangani permasalahan yang ada di toko tersebut. Aplikasi ini memudahkan pekerjaan Admin dalam pembuatan laporan dan memudahkan dalam memproses data pembelian dan penjualan pada Toko Buku Syahputra.

\section{METODE PENELITIAN}

Metode penelitian yang digunakan adalah SDLC (Software Development Life Cycle) yang meliputi analisa kebutuhan, desain, implementasi, pengujian dan evaluasi atau pemeliharaan. Menurut (Rosa dan Shalahuddin, 2016), SDLC atau Software Development Life Cycle adalah proses mengembangkan atau mengubah suatu sistem perangkat lunak dengan menggunakan model-model dan metodologi yang digunakan orang untuk mengembangkan sistem-sistem perangkat lunak sebelumnya. Analisa kebutuhan berguna untuk mendapatkan data-data yang akan digunakan sebagai masukkan dari suatu sistem. Tahap pengujian sistem harus dijalankan untuk mencoba apakah sistem yang dikembangkan dapat bekerja optimal atau tidak. Pada tahap ini, ada beberapa hal yang harus diperhatikan, seperti kemudahan penggunaan sampai pencapaian tujuan dari sistem yang sudah disusun sejak perancangan sistem dilakukan (Putra, 2011).

\section{HASIL DAN PEMBAHASAN}

Dari hasil analisis, permasalahan yang ditemui yaitu :

1. Input data, pencatatan data penjualan maupun pembuatan laporan masih dilakukan secara manual.

2. Proses pencatatan secara manual memerlukan tempat penyimpanan yang sangat luas, akibat kertas yang bertumpuk serta memerlukan waktu yang lama dalam proses pencarian kembali data.

3. Pelayanan terhadap pelanggan menjadi tidak efisien dan rawan terjadi kesalahan akibat waktu yang lama dalam pencarian data.

Berdasarkan permasalahan yang terdapat pada Toko Buku Syahputra, maka dapat dirumuskan alternatif penyelesaian masalah tersebut, yaitu:

1. Membuat rancangan aplikasi yang dapat membantu admin dalam pengolahan data transaksi penjualan dan membuat laporan

2. File atapun data yang sudah diinput sebaiknya disimpan ke Harddisk ataupun alat penyimpanan data lain, dan jika perlu dibuat backup data.

\section{Diagram Kontex}

Aplikasi penjualan pada toko buku Syahputra desainnya menggunakan DFD (Data Flow Diagram), dengan diagram kontex :

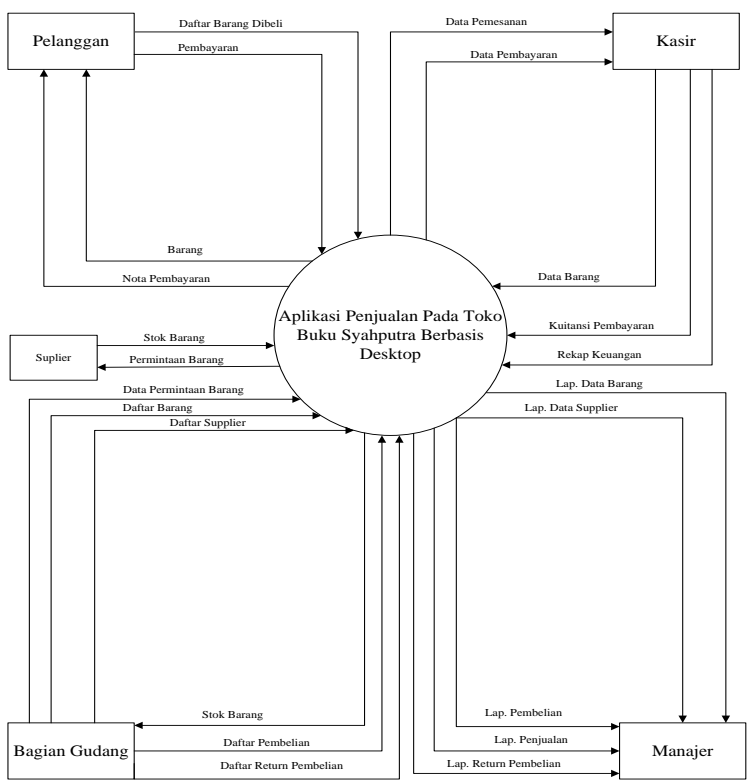

Gambar 1. Diagram Konteks 
Diagram Nol

Kemudian dirinci dalam diagram level 1 (diagram nol)_

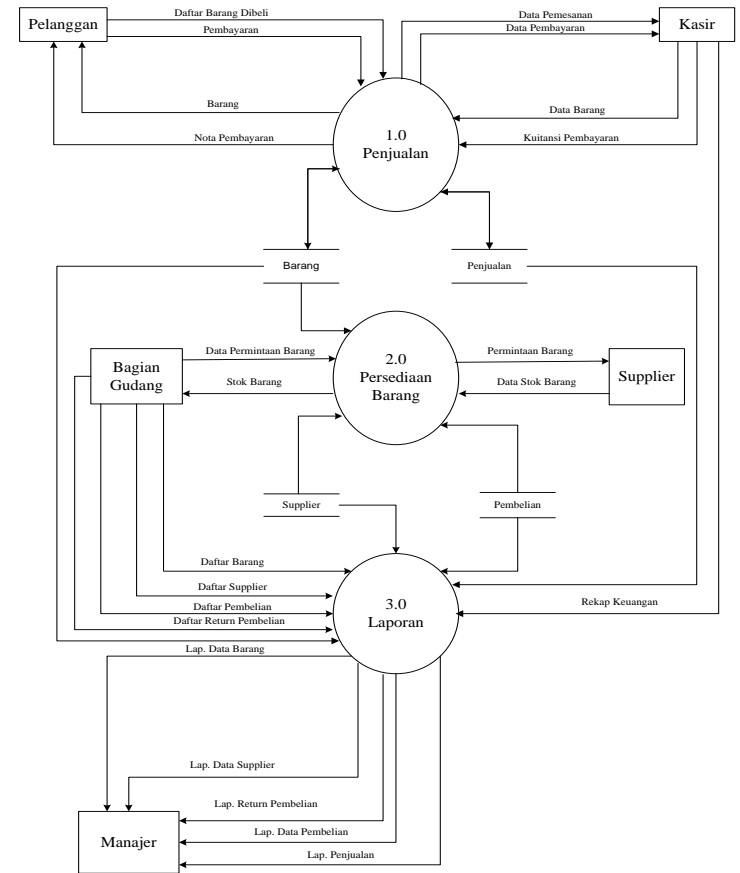

Gambar 2. Diagram Nol

\section{Entity Relationship Diagram}

Entity Relationship Diagram (ERD) adalah pemodelan awal basis data yang akan dikembangkan berdasarkan teori himpunan dalam bidang matematika untuk pemodelan basis data relasional

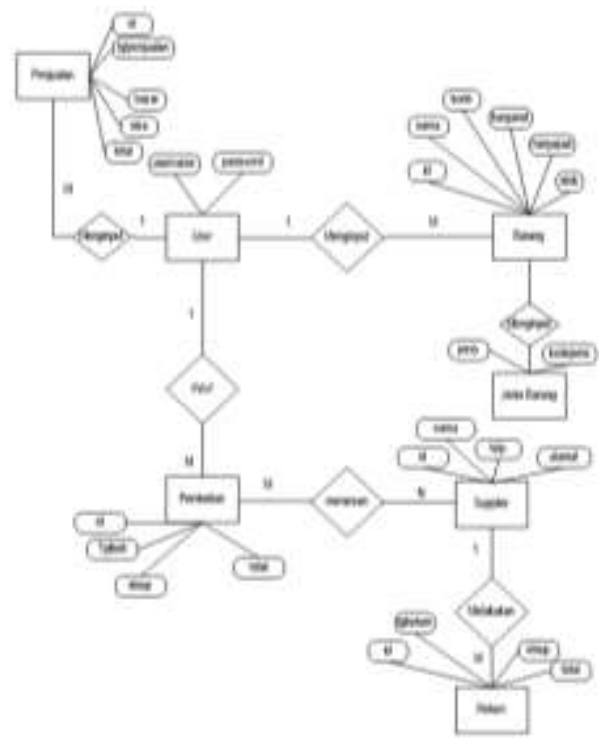

Gambar 3. Entity Relationship Diagram
Tampilan Layar

Berikut adalah tampilan layar dan hasil pengujian pada aplikasi yang di buat dengan bahasa pemrograman Java.

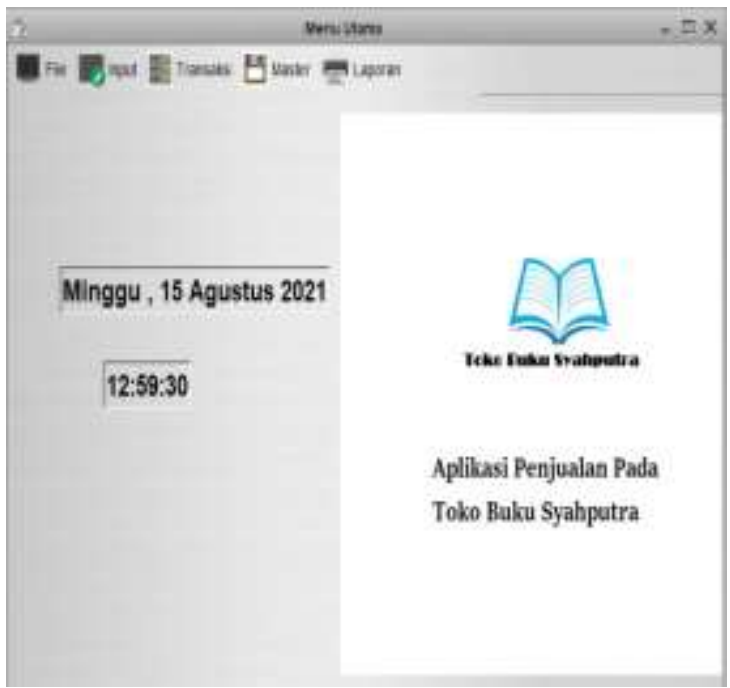

Gambar 4. Form Menu Utama

Layar di atas menampilkan Menu Utama pada Aplikasi Penjualan Pada Toko Buku Syahputra. Pada layar utama tersedia menu bar yang terdiri dari master data yang digunakan untuk memasukkan data yang berkaitan dengan data jenis barang, data barang, data supplier, data pembelian, data penjualan, dan laporan.

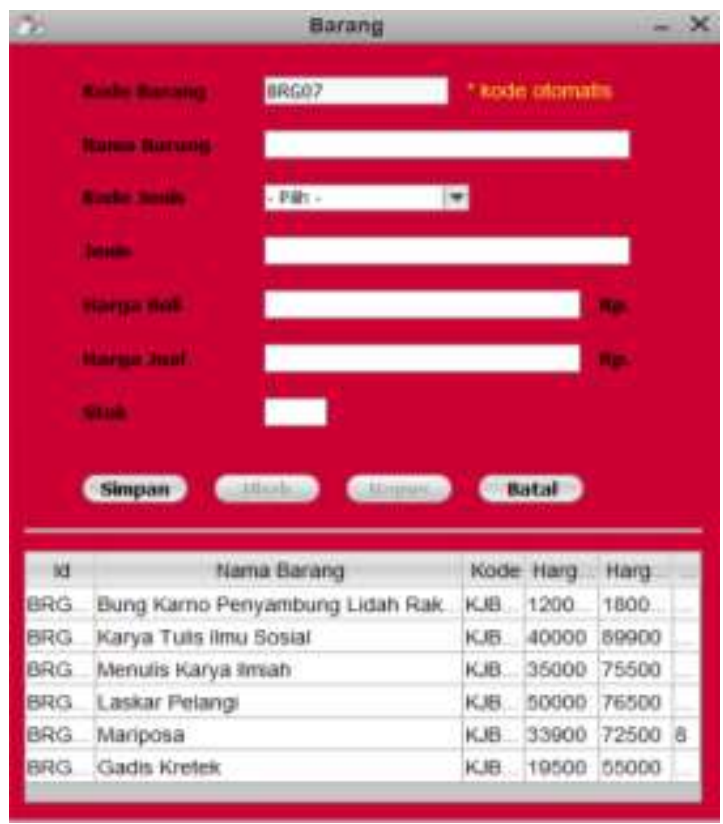

Gambar 5. Form Data Barang

711 | Rancangan Aplikasi Penjualan pada Toko Buku Syahputra Berbasis Desktop 
Layar di atas menampilkan form data barang. Form data barang untuk menginput data barang yang terdiri dari Kode Barang, Nama Barang, Kode Jenis, Jenis Barang, Harga Beli, Harga Jual dan Stok.

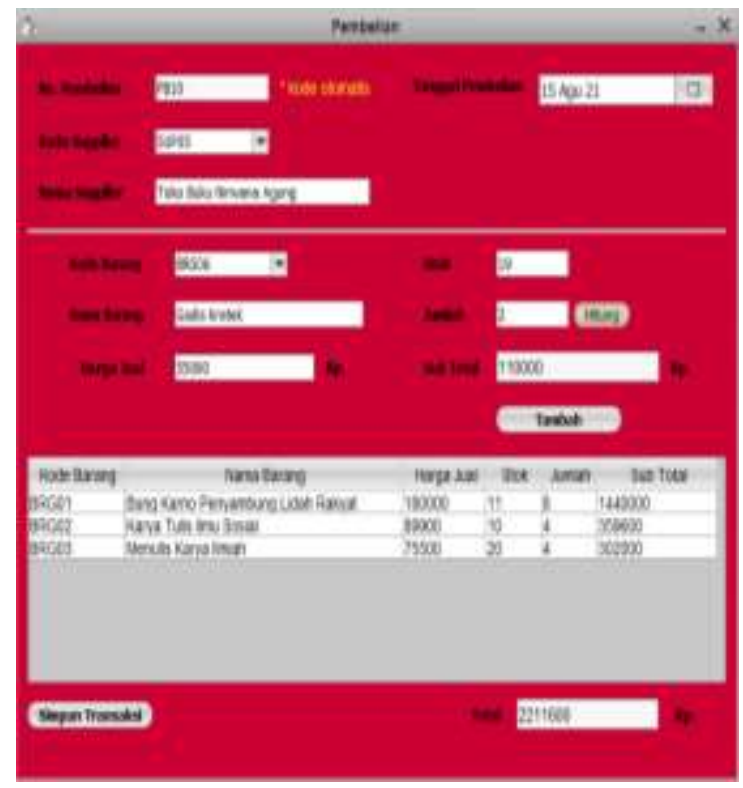

Gambar 6. Data Form Data Transaksi Pembelian

Layar di atas menampilkan form data transaksi pembelian. Form data transaksi pembelian untuk menginput data transaksi pembelian yang terdiri dari No Pembelian, Tgl Pembelian, Kode Supplier, Nama Supplier, Kode Barang, Nama Barang, Harga Jual, Stok, Jumlah dan Sub Total.

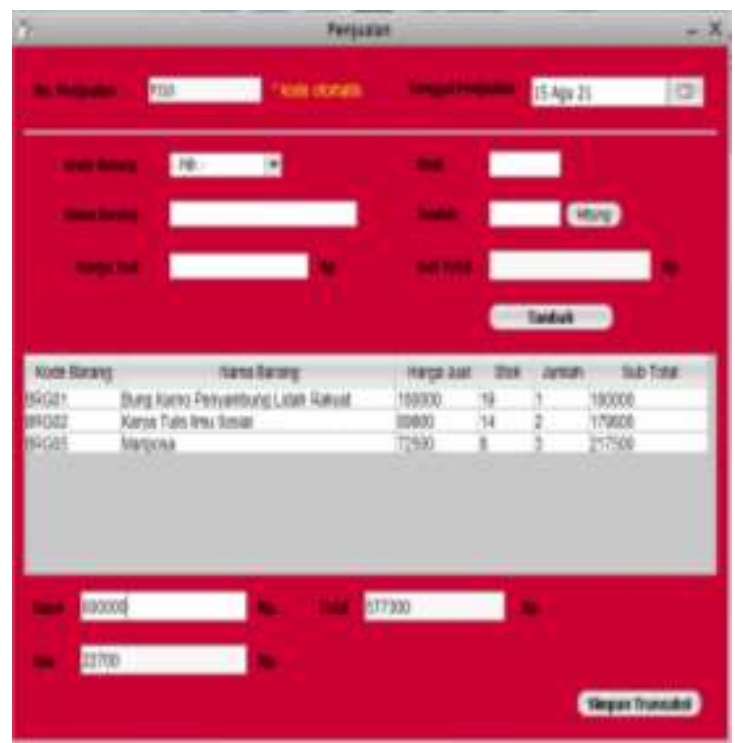

Gambar 7. Form Data Transaksi Penjualan
Layar di atas menampilkan form data transaksi penjualan. Form data transaksi penjualan untuk menginput data transaksi penjualan yang terdiri dari No Penjualan, Tgl Penjualan, Kode Barang, Nama Barang, Harga Jual, Stok, Jumlah dan Sub Total.

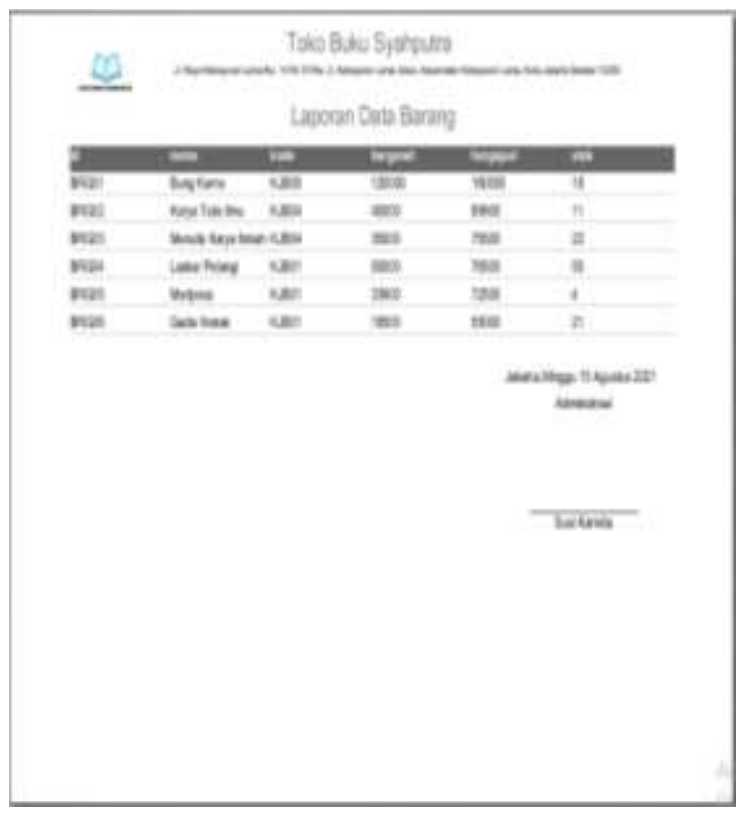

Gambar 8. Laporan Data Barang

Layar di atas menampilkan form laporan data barang. Form laporan data barang digunakan untuk mengecek laporan yang terdiri Kode Barang, Nama Barang, Kode Jenis, Jenis Barang, Harga Beli, Harga Jual dan Stok.

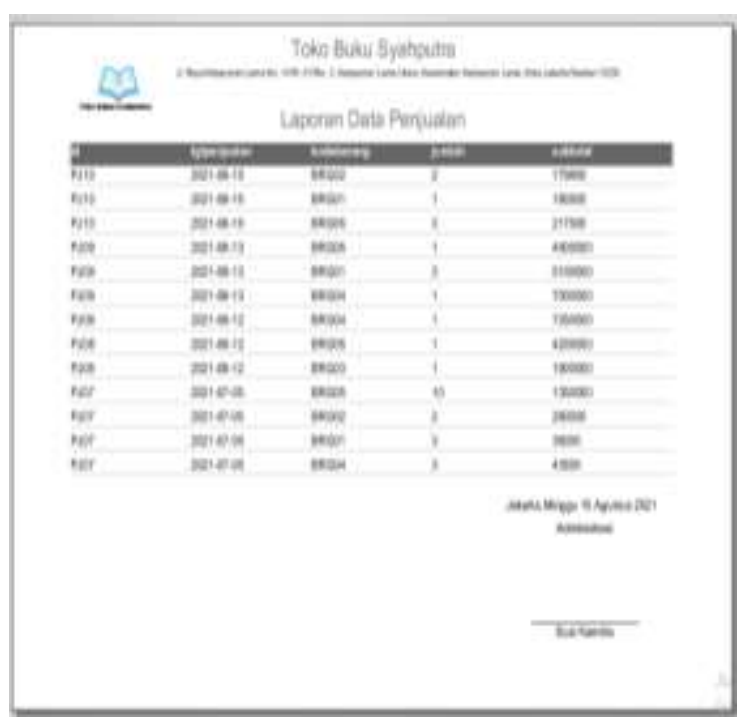

Gambar 9. Laporan Data Penjualan

712 | Rancangan Aplikasi Penjualan pada Toko Buku Syahputra Berbasis Desktop 
Layar di atas menampilkan form laporan data penjualan. Form laporan data penjualan digunakan untuk mengecek laporan data penjualan terdiri No Penjualan, Tgl Penjualan, Kode Barang, Jumlah dan Sub Total.

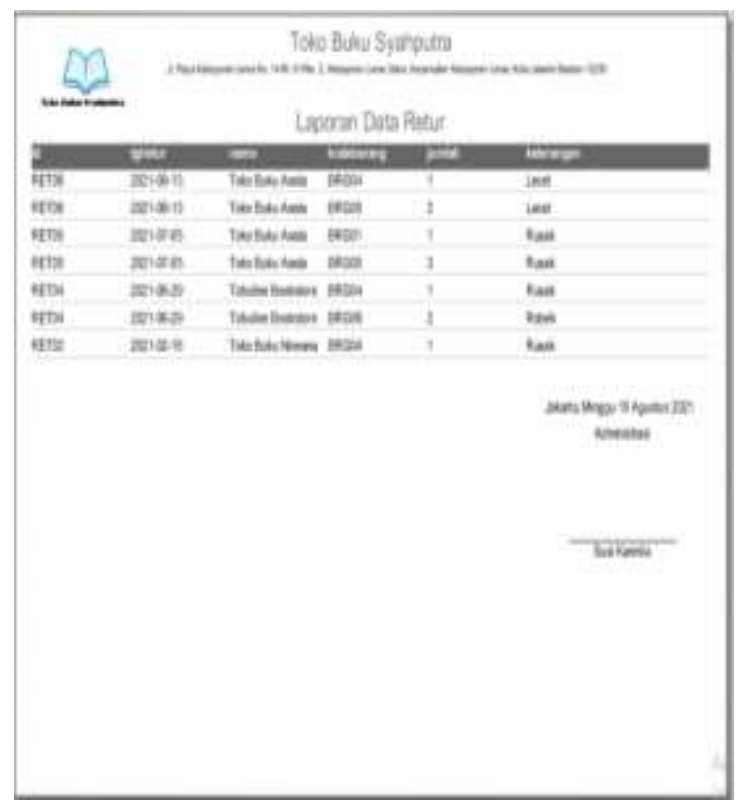

Gambar 10. Laporan Data Return Pembelian

Layar di atas menampilkan form laporan data return pembelian. Form data return pembelian digunakan untuk mengecek laporan data return pembelian terdiri No Return, Tanggal Return, Nama Supplier, Kode Barang, Jumlah, Keterangan.

\section{SIMPULAN DAN SARAN}

Aplikasi yang dirancang sudah layak digunakan untuk proses penjualan pada Toko Buku Syahputra karena sudah sesuai dengan kebutuhan, sehingga dapat mempermudah admin dalam proses penginputan data serta pembuatan laporan. Aplikasi penjualan pada Toko Buku Syahputra dibuat untuk memudahkan admin dalam proses pencarian data seperti data barang, data supplier, data pembelian, data transaksi penjualan serta data return pembelian karena data yang sudah terinput akan tersimpan dengan baik didalam database.
Sarannya adalah keamanan aplikasi perlu dijaga dengan cara backup data dan mempercayakan aplikasi pada karyawan yang bertanggung jawab.

\section{DAFTAR PUSTAKA}

Abdurahman, M. (2017). Sistem INformasi Pengolahan Data Pembelian dan Penjualan Pada Toko Koloncucu Ternate. IJIS - Indonesian Journal On Information System. https://doi.org/10.36549/ijis.v2i1.22

Ali, A. F. (2019). Rancang Bangun Aplikasi Penjualan Barang Berbasis Java Programming. Simtika.

Prasojo, M. (2011). Pengantar Sistem Informasi Manajemen. bandung: CV. Remadja Karya.

Putra, N. (2011). Research and Development, Penelitian dan Pengembangan: Suatu Pengantar. Jakarta: PT Raja Grafindo Persada.

Sari, Y. P. (2017). Rancang Bangun Aplikasi Penjualan Dan Persediaan Di Kota Prabumulih. Jurnal Sistem Informasi Dan Komputerisasi Akuntansi (JSK).

Satzinger, J. W., Jackson, R. B., Burd, S. D. (n.d.). System Analysis and Design in A Changing World. USA: Cengage Learning.

Sholikhah, I., Sairan, M., \& Syamsiah, N. O. (2017). Aplikasi Pembelian Dan Penjualan Barang Dagang Pada CV Gemilang Muliatama Cikarang. Teknik Komputer AMIK BSI, III(1), 16-23.

Sugiyono. (2016). Metode Penelitian Kuantitatif, Kualitatif dan $R \& D$. Bandung: PT Alfabet.

Sutabri, T. (2012). Analisis Sistem Informasi. Yogyakarta: Andi.

Tyoso, J. S. P. (2016). Sistem Informasi Manajemen. Yogyakarta: DeePublish. 